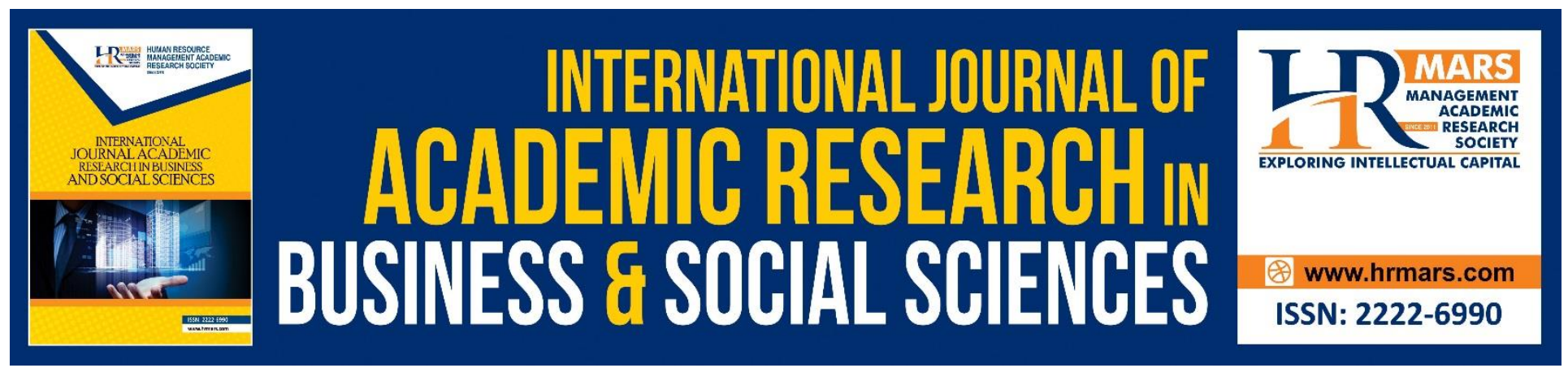

\title{
Beyond the Call of Duty: Determinants and Consequences of Organizational Citizenship Behaviour on Going $21^{\text {st }}$ Century
}

Siti Aishah Edros, Saiful Azley Samsudin, Wan Mohd Razman Wan Yusof

To Link this Article: http://dx.doi.org/10.6007/IJARBSS/v10-i7/7596

DOI:10.6007/IJARBSS/v10-i7/7596

Received: 27 April 2020, Revised: 08 May 2020, Accepted: 21 June 2020

Published Online: 08 July 2020

In-Text Citation: (Edros et al., 2020)

To Cite this Article: Edros, S. A., Samsudin, S. A., \& Yusof, W. M. R. W. (2020). Beyond the Call of Duty: Determinants and Consequences of Organizational Citizenship Behaviour on going 21st Century. International Journal of Academic Research in Business and Social Sciences, 10(7), 671-682.

Copyright: (c) 2020 The Author(s)

Published by Human Resource Management Academic Research Society (www.hrmars.com)

This article is published under the Creative Commons Attribution (CC BY 4.0) license. Anyone may reproduce, distribute, translate and create derivative works of this article (for both commercial and non-commercial purposes), subject to full attribution to the original publication and authors. The full terms of this license may be seen

at: http://creativecommons.org/licences/by/4.0/legalcode

Vol. 10, No. 7, 2020, Pg. 671 - 682

http://hrmars.com/index.php/pages/detail/IJARBSS

JOURNAL HOMEPAGE

Full Terms \& Conditions of access and use can be found at http://hrmars.com/index.php/pages/detail/publication-ethics 


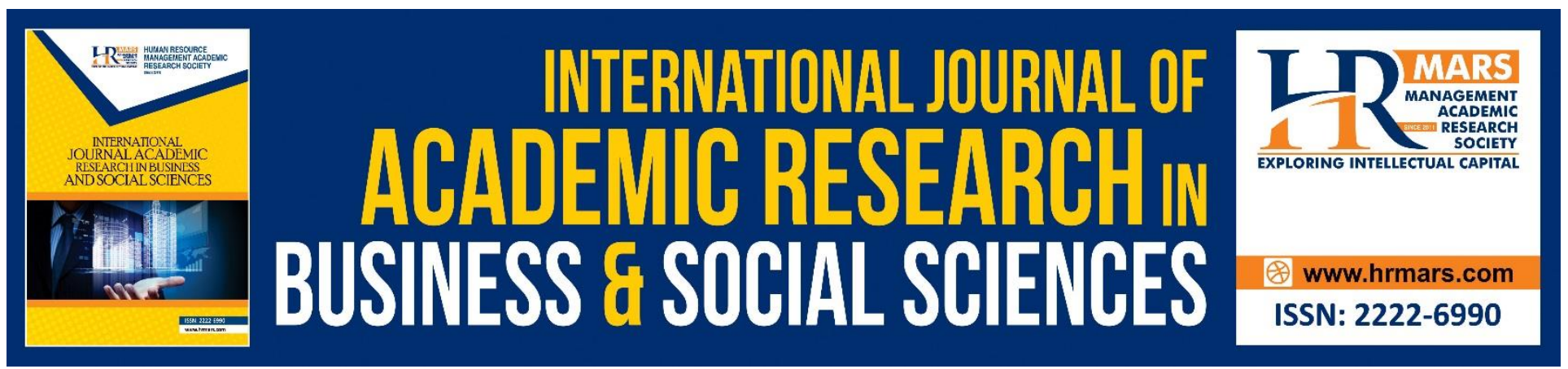

\title{
Beyond the Call of Duty: Determinants and Consequences of Organizational Citizenship Behaviour on Going $21^{\text {st }}$ Century
}

\author{
Siti Aishah Edros ${ }^{1}$, Saiful Azley Samsudin², Wan Mohd Razman \\ Wan Yusof 3 \\ ${ }^{1}$ Faculty of Hotel \& Tourism, Universiti Teknologi Mara, Penang Branch Campus, Malaysia. \\ ${ }^{2}$ Kolej Komuniti Arau, Perlis, Malaysia, ${ }^{3}$ Langkawi Tourism Academy, Kedah, Malaysia.
}

\begin{abstract}
Organizational citizenship behaviour (OCB) is most chosen topics that has being discussed year by year, time by time, among researchers and practitioners. (Karam et al, 2011). A part of that, OCB are the behaviour that not only for the formal tasks but also for conducted the extra role in the organization. (Carpenter et al, 2014.) .This current paper basically will review the several type of OCB, consequences of OCB that novelty of this paper, author will discussed about positive and negative side of $O C B$, Beside that, author will propose the conceptual framework that can be take into consideration in future research Furthermore, author also found ten (10) trend of OCB in this $21^{\text {st }}$ Century that can be the next topic to be discussed in the future in order to get the benefit from OCB dimensions. This paper also have the resources that finds the article which are used the systematic literature review, author use the correct keywords and make sure the eligibility of the information needed. Hence, several keywords were identified to conduct the literature review. In the case of this study, the necessary and relevant supporting materials were obtained using electronic da ta bases available at the university's library databases which include Scopus, SAGE, Academia, and Research Gate. Lastly, author included the conclusion part which are their hopes and beneficial elements to all the reader.
\end{abstract}

Keywords: Organizational Citizenship Behaviour, Consequences, Dimensions of Organization Citizenship Behaviour.

\section{Introduction}

Organizational Citizenship Behaviour

According to Organ 1988, OCB defined are related to the self determination to give extra role for the organizational outcome and not only focusing to the reward in term of monetary purpose only this is the important element of OCB (Smith et al, 1983). In particular, altruism can be defines as helping attitude directed to individual, while general compliance mentions to a helping behaviour directed 
to organization. This is the earlier definition of $O C B$ and the term become wider time to time according to the organization and new outcome of researcher.

The generally accepted dimensions by author Chahal and Mehta, 2010, discussed as OCB under definition by Organ (1988) and Padsakoff et all (1990) that the most referring in OCB field :

i. Altruism: Altruism can be defined as the helping behaviour that as a team of the organization, we need to help others when they having any problems in order to have good result of the organization. This attitude is very important to the high demand industry like hospital, hotel and banking industry.

ii. Conscientiousness: Factors that contribute to the attitude of conscience include upholding the law, being on time after a timely break. This dimension will teach the staff to respect other time and not wasting and extended the time that will be messy up other.

iii. Sportsmanship: This is a willingness to accept less than desirable conditions without complaining, and to refrain from behaviours such as complaining and trivial grievances. Practices of sportsmanship among staff have allowed them to avoid any spread of problems within or outside the department and to develop forgiveness behaviour.

iv. Civic Virtue: These are actions on the part of individuals that show that they are responsible and rationally concerned about the existence of the organization. This is the important factor to make sure every staff have their own self reminder to be a part of the organization and active in their team when having any occasion/event.

v. Courtesy: OCB 's element that also include the politeness a one of the dimensions.

This behaviour is import to develop the staff respectfully each other and if the problems occurred in the organization, they will not be preventing world related problems among each

other's. They will try to always to serve the best to patient and co-worker.

In addition, it should be illustrious that OCB has been extensively studied under different terms such as civic organizational behaviour by Graham et al 1991, extra-role behaviour (Vandyneet al, 1995), contextual performance (Motowidlo et al, 1999), perceived organizational membership (Masterson et al, 2003), and compulsory citizenship behaviour (Vigoda-Gadot et al,2006). Therefore, it can be determined that several concepts of OCB tend to result in the inadequate definition of this construct. In conjunction with that, Williams and Anderson (Williams et al, 1991) have further categorized OCB into individuals or organizations by respectively representing them as OCBI and OCBO. In 2017, based on the review from The Journal of Applied Psychology stress out that OCB is the topic that will never stop being discovery because their impact towards the employee and organization outcome. (Kozlowski, Chen, \& Salas, 2017). It is clearly telling the research OCB is the topic that always being relevance to studies in the future.

\section{Types of Organization Citizenship Behaviour}

This approach has successfully been used as far back as 1900s, when as described by Organ (1988) and Organ, Podsakoff, and MacKenzie (2006), lots of organizational scholar are agreed that OCB are the most arguing topic because this is not only done the formal task but also informal tasks that need to increase by the employee. For instance, Barnard (1938), he reported that as an employee we need to helps other; besides the researcher also suggested that element of sustainable or loyalty employee should develop in the organization (Organ, 1977, p. 50).

From the author reading, Bateman and Organ (1983) published the first empirical study of OCB stated that when employee engagement with the organization, the level of OCB will higher and the 
INTERNATIONAL JOURNAL OF ACADEMIC RESEARCH IN BUSINESS AND SOCIAL SCIENCES Vol. 10, No. 7, July, 2020, E-ISSN: 2222-6990 @ 2020 HRMARS

employee will take care the asset, have a good time of training and will be more satisfy with any event in the organization.

Over the past 35 years, researchers have identified a number of different types of OCBs (Figure 1.0), and several author that put their efforts to write and do research about OCB and connected with other variable that can lead to the better employee performance and organizational outcomes (Podsakoff et al., 2000).

Figure 1.0 are telling the readers that OCB are the behaviour that are really important and will always being studies time by time to increase and fill the gaps after studying about this topic. This consequence of OCB will be explored time by time and will be improvise in the future to have more positive impact but maybe now the researcher also finds out that $O C B$ also can bring the negative impact if the management don't know how to manage this.

From the author review about the factor culture also can affect the OCB in term of the diversity of the employee. That being supported by Ang \& Dyne, (2015), agreed that culture also as the predicator to increase the OCB in term of sharing the language and culture of a country. Respectful of other culture will bring the good value for increasing the OCB in an employee.

\begin{tabular}{|c|c|}
\hline Author(s) (year) & Measures/Types of OCBs \\
\hline \multirow[t]{2}{*}{ Smith et al. (1983) } & Altruism (helping others) \\
\hline & General compliahce (following rules and punctuality) \\
\hline \multirow{5}{*}{$\begin{array}{l}\text { Organ (1988) and } \\
\text { Podsakoff et al. } \\
\text { (1990) }\end{array}$} & Altruism (helping others) \\
\hline & Conscientioushess (being punctual and reliable) \\
\hline & Sportsmanship (refraining from complaining) \\
\hline & Courtesy (touching base with others) \\
\hline & Civic virtue (being involved) \\
\hline \multirow[t]{4}{*}{ Van Dyne et al. (1994) } & Loyalty (defending the organization) \\
\hline & Obedience (being punctual and obeying rules) \\
\hline & Social participation (being involved) \\
\hline & $\begin{array}{l}\text { Advocacy participation (being outspoken) } \\
\text { Functional participation (taking on additional responsibilities) }\end{array}$ \\
\hline \multirow{4}{*}{$\begin{array}{l}\text { Moorman and Blakely } \\
\text { (1995) }\end{array}$} & Interpersonal helping (helping others) \\
\hline & Individual initiative (being outspoken) \\
\hline & Personal industry (being punctual and careful in their work) \\
\hline & Loyal boosterism (defending and promoting the company) \\
\hline \multirow[t]{6}{*}{ Podsakoff et al. (2000) } & $\begin{array}{l}\text { Helping behavior (helping others and giving assistance) } \\
\text { Sportsmanship (not complaining) }\end{array}$ \\
\hline & Organizational loyalty (defending the organization) \\
\hline & Orgahizational compliance (following rules) \\
\hline & Individual initiative (being proactive) \\
\hline & Civic virtue (being involved) \\
\hline & Voice (speaking up about concerns) \\
\hline \multirow{3}{*}{$\begin{array}{l}\text { Coleman and Borman } \\
\text { (2000) }\end{array}$} & Interpersonal citizehship performance (helping/cooperating with coworkers) \\
\hline & $\begin{array}{l}\text { Organizational citizenship performance (supporting, defending the } \\
\text { organization, and following rules) }\end{array}$ \\
\hline & Job/task conscientioneshess (persisting with extra effort to complete tasks) \\
\hline \multirow{2}{*}{$\begin{array}{l}\text { Williams and Anderson } \\
\text { (1991) }\end{array}$} & $O C B-I$ (citizenship behaviors aimed at individuals) \\
\hline & $O C B-O$ (citizenship behaviors aimed at organization) \\
\hline \multirow{2}{*}{$\begin{array}{l}\text { Van Dyne and LePine } \\
\text { (1998) }\end{array}$} & Helping (affiliative citizenship behavior) \\
\hline & Voice (challenging citizenship behavior) \\
\hline \multirow[t]{6}{*}{ Farh et al. (1997) } & Sportsmahship (specific to Western cultures) \\
\hline & Courtesy (specific to Western cultures) \\
\hline & Interpersonal harmony (specific to Chinese cultures) \\
\hline & Protecting company resources (specific to Chinese cultures) \\
\hline & Idehtification with company (universal OCB-similar to civic virtue) \\
\hline & Conscientioushess (universal OCB-being punctual and reliable) \\
\hline \multirow[t]{4}{*}{ Dekas et al. (2013) } & Helping (helping coworkers) \\
\hline & Voice (speaking up about concerns) \\
\hline & Civic virtue (being involved) \\
\hline & Social participation (engaging in work-related activities) \\
\hline
\end{tabular}

Figure 1: Categories of Organization Citizenship Behaviour (Source: Harvey et al, 2018) 
Regarding the many type of the OCB, it's made the initiative by Le Pine, Erez, and Johnson (2002), to do the meta - analysis of OCB. The finding is found that the numerous types of OCB are highly correlated each other have their value to the organization outcome. However, as discussed by Bolino and Grant (2016), there are still have inconsistency of measuring the meaning of OCB.

From the great author knowledge, no matter how OCB are being conceptualize the benefits of OCB can be stated as "beyond the call of duty" and obviously being participant behaviours that help other specific individuals and that help the organization, this may involve observing the obligations of the organization or challenging them in a positive way, but it may also involve acting in a manner or performing tasks at such a high level or with such care that it exceeds what might normally be expected of the employee.

\section{Consequences of OCB - Positive and Negative Aspects}

The study by Chughtai and Zafar, 2006; Khalid and Ali, 2005; Meyer et.al, 1997; Podaskoff and Mackenzie, 1997 stated that OCB has a key predictor or antecedence of the job performance. Generally, it has been debated organization that have higher level of OCB in the employee will helps the company to reduce the tendency of turnover and negative behaviour like absenteeism and immoral attitude by the employee.

The empirical or previous study keep on debated about the consequences of having OCB. These dimensions are explained below by Chughtai and Zafar, 2006; Khalid and Ali, 2005; Meyer et.al, 1997; Podsakoff and Mackenzie, 1997:

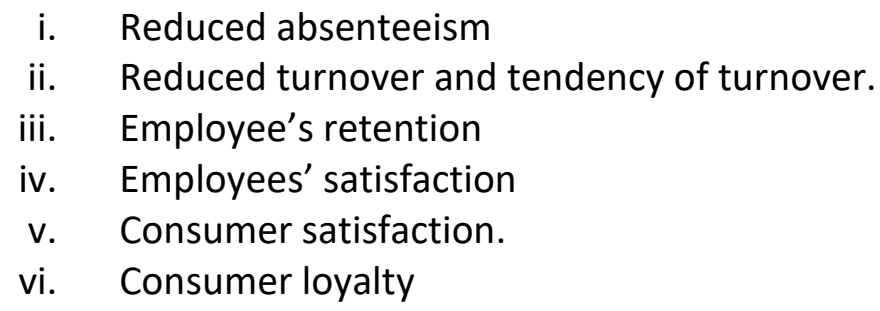

From the best level of author knowledge, the consequences of OCB also can illustrated in the negative ways instead of positive outcome. Indeed, the basic of OCB outcome may increase the pressure of employee if there are too kind all the time (Bolino et al., 2010; Bolino et al., 2015). Consequently, in the further research the outcome of OCB needs to be fair in both perceptive not only what the employer wants. Besides, to overcome the matter, the measure of both side which are employee and employee should be taken in consideration (Chahal \& Mehta, 2011).

Based on the article by Harvey et al, (2018), instead of discussing about antecedents of OCB, the researcher also discussed about consequences of OCB which are: positive and negative outcome, negative employee outcome and group and organization outcome. All the consequences are discussed in detailed and also mention the researcher that done the study about it. Surprisingly, there are lots of researcher that found the negative or bad side of OCB instead of positive impact, Bergeron (2007) and Bergeron et al. $(2013,2014)$ instead of OCB re great attitude but if the organization failed to address it the wise way, it will make the employee frustrated. Bolino and Turnley (2005) and 
Halbesleben et al. (2009), studies about OCB also lead to negative consequences like job stress, frustration and demotivated. Bolino et al. (2015), initiate that OCB stress that OCB can make employee feel exhausted and stressful and that are supported by the research of Klotz and Bolino (2013); Bolino and Klotz (2015); and Yam et al. (2017); Koopman et al. (2016) agreed with their empirical result that OCB will be more decrease goal and lead to hurt job satisfaction and lead to stress. All this studies, reveal that $O C B$ in the new era of $21^{\text {st }}$ Century and there must have to take extra attention for all the researcher for their future studies.

Dyne and Ellis (2004) developed a theoretical model that shown the impact if the OCB are not being treated well by the employer towards the employee which can lead losing of the great employee in the organization in the future. Some scholars have criticized the process used to introduce OCBrelated constructs (LePine et al., 2002). For example, most research which proposed new types of OCB used factor analysis to identify and support different types of OCB. (Spitzmuller, Van Dyne, \& Ilies, 2008) Unfortunately, however, very few studies have inspected the potential conceptual overlap of the resulting constructs (Van Dyne and colleagues, 1995; and LePine et al., 2002).

For the attention of researcher, there are few research on the consequences of performing OCB for those who perform OCB. As a researcher, all of us need to find the solution and give the attention to make sure $O C B$ are being directly in a good outcome rather that wrongly negatively (Bateman and Organ, 1983; Park and Van Dyne, 2006).

\section{Managerial Implications}

Podsakoff and Mackenzie, 1997 reported that OCB can give lots of benefit to organization performance like reduce turnover, absenteeism and low motivation. The reflection of the good effect of $O C B$ need to be manage and understand well by the top management in order to strengthening the correlation with consumers, enhancing organizational image and eventually organizational performance. Better understanding of the individual behaviour in organization (OCB) will help the industry player in all type of organization. (Meyer et al., 2007). Hence, pursuing such type of study, at local, national and global levels, could provide roadmap for the organizations in strengthening the relationship with customers, building robust image and competitive advantage over competitors through customer's satisfaction and loyalty. 


\section{Conceptual Framework}

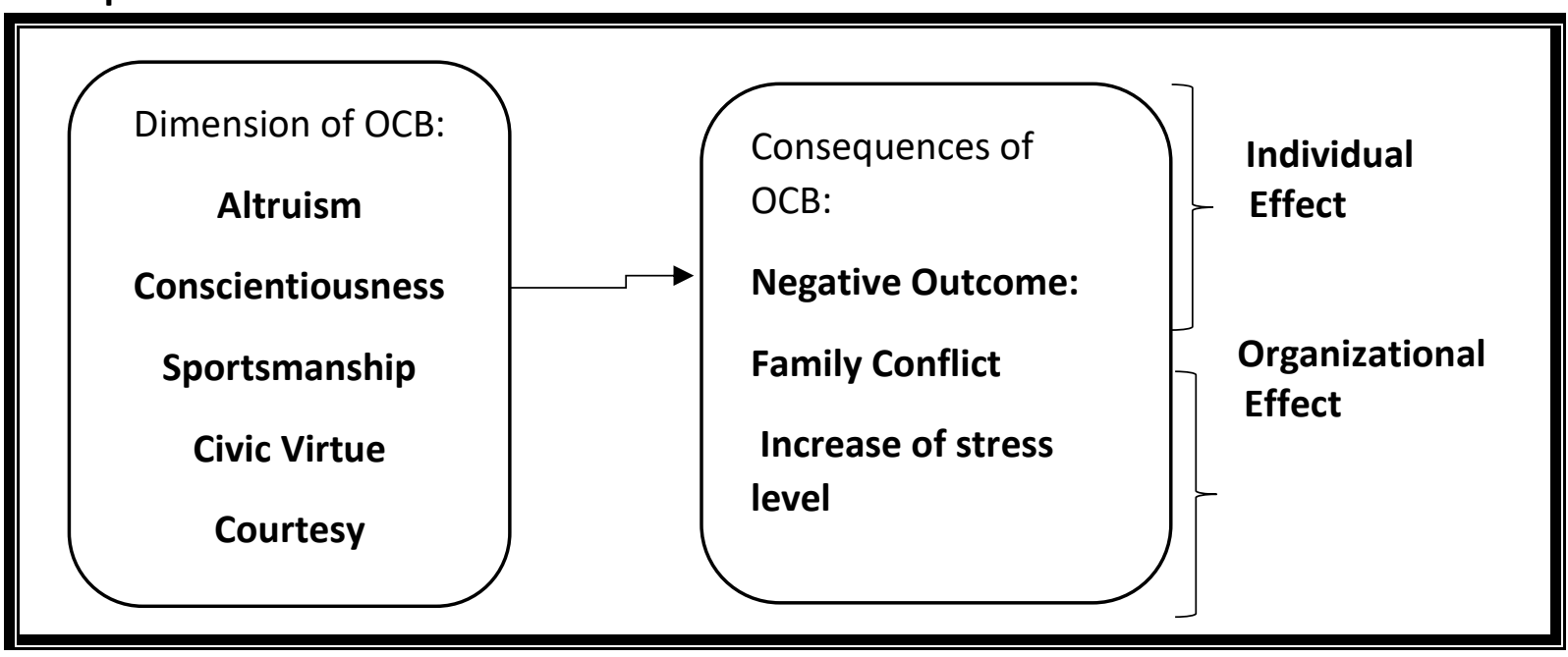

Based on the conceptual framework above, author suggested that in the future studies this will give the empirical result that will show the most significant factors among the dimension of OCB that contribute to the negative outcome of OCB. Furthermore, it will generate the new ideas and argument based on the previous study that have done by another researcher. And the main objective is to fill the gaps where there a few studies of negative outcome of OCB held. Besides that, the author also suggest that the consequences of OCB will lead to individual and organizational effect.

\section{Workplaces Trends related to Human Resources Management in $\mathbf{2 1}^{\text {st }}$ Century.}

For decades OCB has been of attention to researchers and industry player alike, generating a significant amount of research exploring the concept of what citizenship behaviour is, and its antecedents, correlates, and consequences. All these while OCB have been treasured and will continue to be valuable, there are changes in the workplace that have the potential to modify what types of OCBs will remain important for organizations in the future, as well as what types of opportunities for OCB happen for employees. To the best author knowledge, study by Harvey et al, 2018 , they build on these trends that others have identified as having the potential to shape the workplace of the future, which include: 


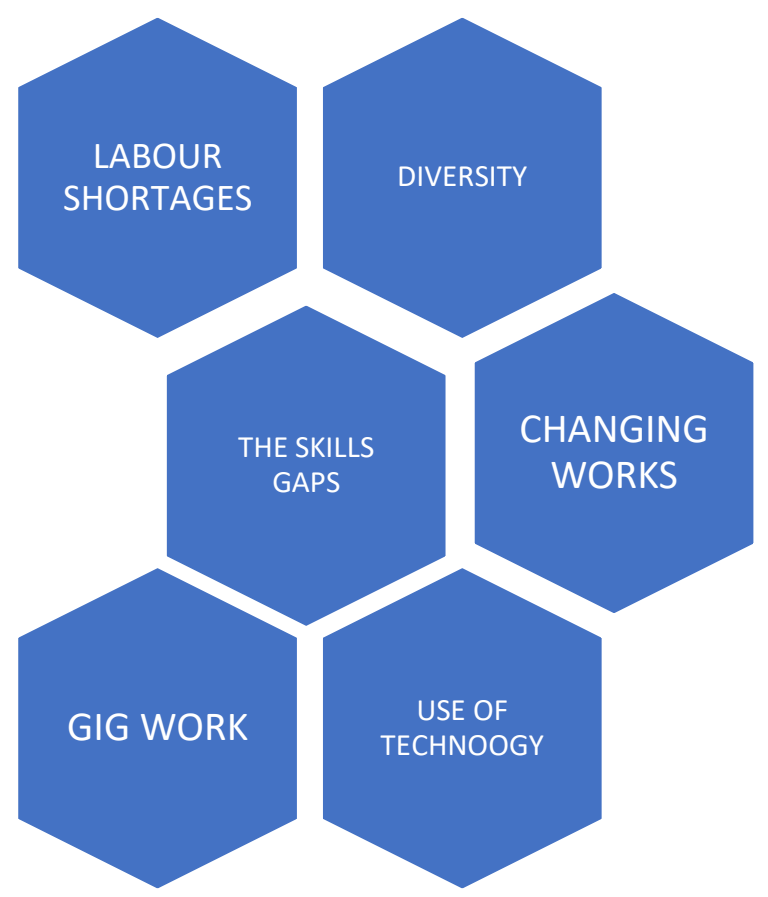

Although over 40 years there are proven that OCB helps the organization to go beyond when the employee are go beyond of their work scope. However, the world of work has changed since the 1930s, or even the 1980s, and researchers have identified several trends that will characterize the workplace of the twenty-first century based on the technologies changes, lots of employee need to have the balance well-being and being understood by the organization (Harvey et al, 2018).

\section{Conclusion}

It has been decades since Katz (1964) observed that to increase the effectively organization its start from the extra mile's employee. Since that time, it has become transparent that OCBs help both individuals and organizations (Bolino et al., 2002; Organ et al., 2006; Podsakoff et al., 1997, 2009; Podsakoff \& MacKenzie, 1997), which suggests that they will continue to be part of organizational life in the future. In this paper, the studies also found the negative consequences of OCB that need to have more attentive in order to retain the employee and stay longer at the organization. Hence, the trends of OCB in this $21^{\text {st }}$ century need to be alert of all the manager in order to fill the loops of the employee and world needed.

In conclusion, OCB has shown to bring important the good consequences toward both parties but its not possible to became negative effect if the organization are not well managing the great employee that have high level of OCB because it may turn to demotivated employee and maybe the organization will loose the great employee. This is supported by statement Vargo and Lusch, (2004) the well manage employee with high OCB will give the benefit to the service industry like hotel and airline that are not fully of the back to back working shift.

Hopefully, the current paper would be very useful in attracting more scholarly attention in conducting more individual- and organizational-related studies that can further contribute to the new 
INTERNATIONAL JOURNAL OF ACADEMIC RESEARCH IN BUSINESS AND SOCIAL SCIENCES

Vol. 10, No. 7, July, 2020, E-ISSN: 2222-6990 @ 2020 HRMARS

dimensions of organizational behaviour. Finally, the knowledge on this issue can be enhanced time to time.

\section{Acknowledgement}

My special acknowledgement for my colleagues (co-author) and my lecturer at Faculty of Hotel \& Tourism Management at UITM Penang Branch Malaysia that have helped in conducting this study.

\section{Corresponding Author}

Siti Aishah Edros. Faculty of Hotel \& Tourism, Universiti Teknologi Mara,

Penang Branch Campus, Malaysia.

Email: aishahedros88@gmail.com

\section{References}

Ang, S., \& Van Dyne, L. (2015). Handbook of cultural intelligence. Abingdon: Routledge.

Applied Psychology, 90, 740-748.Background, evolution, and scientific trends. Journal of Applied Psychology, 102, 237-253.

Barnard, C. I. (1938). The functions of the executive. Cambridge, MA: Harvard University Press.

Bateman, T. S., \& Organ, D. W. (1983). Job satisfaction and the good soldier: The relationship between affect and employee "citizenship", Academy of Management Journal, 26 (4): 587595. Behaviour. Journal of International Review of Industrial and Organizational Psychology.

Bergeron, D. M. (2007). The potential paradox of organizational citizenship behavior: Good citizens at what cost?. Academy of Management Review, 32, 1078-1095.

Bergeron, D. M., Shipp, A. J., Rosen, B., \& Furst, S. A. (2013). Organizational citizenship behaviour and career outcomes: The cost of being a good citizen. Journal of Management, 39, 958-984.

Bergeron, D., Ostroff, C., Schroeder, T., \& Block, C. (2014). The dual effects of organizational citizenship behavior: Relationships to research productivity and career outcomes in academe. Human Performance, 27, 99-128.

Bolino, M. C., \& Klotz, A. C. (2015). The paradox of the unethical organizational citizen: The link between organizational citizenship behavior and unethical behavior at work. Current Opinion in Psychology, 6, 45-49.

Bolino, M. C., \& Turnley, W. H. (2005). the personal costs of citizenship behavior: the relationship between individual initiative and role overload, job stress, and work-family conflict. Journal of Applied Psychology, 90, 740-748.

Bolino, B. M. C., Hsiung, H. H., Harvey, J., \& LePine, J. A. (2015). Well, I'm tired of tryin!Organizational citizenship behavior and citizenship fatigue. Journal of Applied Psychology, 100, 56-74.

Bolino, M. C., Klotz, A. C., \& Turnley, W. H. (2016). The unintended consequences of organizational citizenship behaviors for employees, teams, and organizations. in P. Podsakoff, S. Mackenzie, \& N. Podsakoff (Eds.), Oxford handbook of organizational citizenship behavior. DOi: 10.1093/ oxfordhb/9780190219000.013.11.

Bolino, M. C., Klotz, A. C., Turnley, W. H., \& Harvey, J. (2013). Exploring the dark side of organizational citizenship behavior. Journal of Organizational Behavior, 34, 542-559.

Bolino, M. C., Turnley, W. H., \& Bloodgood, J. M. (2002). Citizenship behavior and the creation of social capital in organizations. Academy of Management Review, 27, 505-522. 
INTERNATIONAL JOURNAL OF ACADEMIC RESEARCH IN BUSINESS AND SOCIAL SCIENCES

Vol. 10, No. 7, July, 2020, E-ISSN: 2222-6990 @ 2020 HRMARS

Carpenter, N. C., Christopher, M. B., \& Houston, L. (2014). A meta-analytic comparison of selfreported and other-reported organizational citizenship behavior. Journal of Organizational Behavior, 35, 4 , 547- 574.

Chahal, H. (2008). A Multiple Item Scale for Measuring Consumer Satisfaction in National Public Health Care Services. Major Research Project, UGC, New Delhi, 20-34.

Chahal, H., \& Mehta, S. (2010). Antecedents and Consequences of Organisational Citizenship Behaviour (OCB): A Conceptual Framework in Reference to Health Care Sector. Journal of Services Research, 10(2), 25-44.

Chughtai \& Zafar, S. (2006), Antecedents and Consequences of Organisational Commitment among Pakistani University Teachers. Applied HRM Research, 11(1), 39-64.

Louis, A. P., John, F. D., Jane, A. P., David, A. S. (2005). Prosocial behavior: Multilevel perspectives. Annual Review of Psychology, 56: 365-392.

Gallarza, M. G., \& Saura, G. I. (2006). Value Dimensions, Perceived Value, Satisfaction and Loyalty: An Investigation of University Students' Travel Behaviour. Tourism Management, 27, 437452.http://dx.doi.org/10.1016/j.tourman.2004.12.002

Graham, J. W. (1991). An essay on organizational citizenship behavior. Employee Responsibilities and Rights Journal 4, 4, 249-270.

Harvey, J., Bolino, M. C., \& Kelemen, T. K. (2018). Organizational citizenship behavior in the 21st century: How might going the extra mile look different at the start of the new millennium? Research in Personnel and Human Resources Management, 36(July), 51-110. https://doi.org/10.1108/S0742-730120180000036002

Karam, C. M. (2011). Good organizational soldiers: conflict-related stress predicts citizenship behavior. International journal of conflict management, 22(3), 300-319. http://dx.doi.org/10.1108/10444061111152982

Katz, D. (1964). The motivational basis of organizational behavior. Systems Research and Behavioral Science, 9, 131-146.

Kersnik, J. (2001), Determinants of Customer Satisfaction with the Health Care System,With the Possibility to Choose a Personal Physician and with a Family Doctor in a Transition Country. Health Policy, 13(4), 290-299.

Khalid, S. A., and Hassan, A. (2005), The Effects of Organizational Citizenship Behaviour on Withdrawal Behaviour: A Malaysian study, International Journal of Management and Entrepreneurship, 1(1), 30 - 40. -64

Koopman, J., Lanaj, K., \& Scott, B. A. (2016). Integrating the bright and dark sides of OCB: A daily investigation of the benefits and costs of helping others. Academy of Management Journal, 59, 414-435.

Kozlowski, S. W., Chen, G., \& Salas, E. (2017). One hundred years of the Journal of Applied Psychology.

LePine, J. A., Erez, A., \& Johnson, D. E. (2002). The nature and dimensionality of organizational citizenship behavior: A critical review and meta-analysis. Journal of Applied Psychology, 87 (1), 52-65.

Masterson, S. S., \& Christina, L. S. (2003). Perceived organizational membership: An aggregate framework representing the employee-organization relationship. Journal of Organizational Behavior: The International Journal of Industrial, Occupational and Organizational Psychology and Behavior, 24, 5, 473-490. 
INTERNATIONAL JOURNAL OF ACADEMIC RESEARCH IN BUSINESS AND SOCIAL SCIENCES

Vol. 10, No. 7, July, 2020, E-ISSN: 2222-6990 @ 2020 HRMARS

Sandada, M., \& Zungu, F. (2016). Assessing the Impact of the Predictors of Organisational Citizenship Behaviour in the Hospitality Industry in Zimbabwe. University of Zimbabwe, Graduate School of Management, Euro Economic, Issue 1(35)/2016 ISSN: 1582-8859.

Meyer, J. P., Organ, D. W., \& Graham, J. W. (1997). Individual Performance Attitudes and Motowidlo, Stephan J., and Mark J. Schmit. Performance assessment in unique jobs." Pulakos (Eds.), the changing nature of performance, 56-86.

Organ, D. W. (1977). A reappraisal and reinterpretation of the satisfaction-causes- performance hypothesis. Academy of Management Review, 2, 46-53.

Organ, D. W. (1988). A restatement of the satisfaction-performance hypothesis. Journal of Management, 14, 547-557.

Organ, D. W., Podsakoff, P. M., \& MacKenzie, S. B. (2006). Organizational citizenship behavior: Its nature, antecedents, and consequences. Thousand Oaks, CA: SAGE.

Organ, D. W. (1988). Organizational citizenship behavior: The good soldier syndrome. Lexington Books/DC Heath and Com, 1988. oxfordhb/9780190219000.013.11.

Park, G., \& Van Dyne, L. (2006) Effects of motivational fit on satisfaction with organizational citizenship behaviors. Paper presented at the Society for Industrial and Organizational Psychologists.

Podsakoff, P. M., \& MacKenzie, S. B. (1997). Impact of organizational citizenship behavior on organizational performance: A review and suggestion for future research. Human Performance, 10, 133-151

Podsakoff, P. M., Ahearne, M., \& MacKenzie, S. B. (1997). Organizational citizenship behavior and the quantity and quality of work group performance. Journal of Applied Psychology, 82, 262269.

Podsakoff, P. M., \& MacKenzie, S. B. (1997). Impact of organizational citizenship behavior on organizational performance: A review and suggestions for future research. Human Performance, 10 (2), 133-151.

Sivadas \& Baker, P. (2000). An Examination of the Relationship between Service Quality, Customer Satisfaction and Store Loyalty. International Journal of Retailing and Distribution Management, 28(2), 73-82.

Smith, C. A., Organ, D. W., \& Near, J. P. (1983). Organizational citizenship behavior: Its nature and antecedents. Journal of Applied Psychology, 68, 4, 653-663.

Spitzmuller, M., Van Dyne, L., \& Ilies, R. (2008). Organizational citizenship behavior: A review and extension of its nomological network. The SAGE Handbook of Organizational Behavior: Volume I Micro Approaches, 106-123. https://doi.org/10.4135/9781849200448.n7

Van Dyne, L., \& Ellis, J. B. (2004). Job creep: A reactance theory perspective on organizational citizenship behavior as over-fulfillment of obligations, in J.A.M. Coyle-Shapiro, L.M. Shore, M.S. Taylor and L.E. Tetrick (Eds), The employment relationship: Examining psychological and contextual perspectives. Oxford, UK: Oxford University Press. pp. 181-205.

Van Dyne, L., Cummings, L. L., \& Parks, M. J. (1995). Extra-role behaviors: In pursuit of construct and definitional clarity (A bridge over muddied waters). Research in organizational behavior, 17,215-285.

Vargo, S., \& Lusch, R. F. (2004). The four Service Marketing myths: Remnants of a Goods-based, manufacturing model. Journal of service research, 6(4), pp. 324-335 
INTERNATIONAL JOURNAL OF ACADEMIC RESEARCH IN BUSINESS AND SOCIAL SCIENCES

Vol. 10, No. 7, July, 2020, E-ISSN: 2222-6990 @ 2020 HRMARS

Vigoda-Gadot, E. (2006). Compulsory Citizenship Behavior: Theorizing some dark sides of the good soldier syndrome in organizations. Journal for the Theory of Social Behaviour 36, 1,77-93.

Williams, L. J., \& Stella, E. A. (1991). Job satisfaction and organizational commitment as predictors of organizational citizenship and in-role behaviors. Journal of Management, 17, 3, 601-617.

Yam, K. C., Klotz, A. C., He, W., \& Reynolds, S. J. (2017). From good soldiers to psychologically entitled: Examining when and why citizenship behavior leads to deviance. Academy of Management Journal, 60, 373-396. 